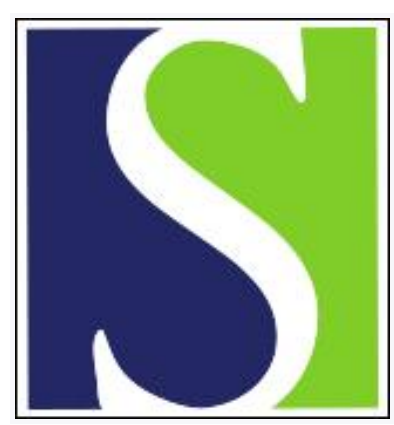

Scand J Work Environ Health 2019;45(3):248-255

https://doi.org/10.5271/sjweh.3784

Published online: 02 Nov 2018, Issue date: 01 May 2019

Historical changes in chemical exposures encountered by Danish firefighters

by Pedersen JE, Petersen KU, Hansen J

Using historical methods, this paper constitutes the first step in describing and evaluating overall historical changes in the firefighter profession in Denmark.

Affiliation: The Danish Cancer Society Research Center, Strandboulevarden 49, 2100 Copenhagen $\varnothing$, Denmark. juliep@cancer.dk

Key terms: chemical exposure; Danish firefighter; Denmark; exposure; exposure assessment; exposure assessment methodology; extreme environment; firefighter; fireman; historical change; history science method; methodology; smoke exhaust; truck exhaust

This article in PubMed: www.ncbi.nlm.nih.gov/pubmed/30614505 


\title{
Historical changes in chemical exposures encountered by Danish firefighters
}

\author{
by Julie Elbæek Pedersen, MSPH, ${ }^{1}$ Kajsa Ugelvig Petersen, MD, ${ }^{1}$ Johnni Hansen, PhD ${ }^{1}$
}

\begin{abstract}
Pedersen JE, Petersen KU, Hansen J. Historical changes in chemical exposures encountered by Danish firefighters. Scand J Work Environ Health. 2019;45(3):248-255. doi:10.5271/sjweh.3784
\end{abstract}

\begin{abstract}
Objective This study aimed to demonstrate the possibility of using history science methods in occupational studies by evaluating overall historical changes in Danish firefighting modifying chemical exposures from smoke and fire trucks.

Methods Data on changes in Danish firefighting after World War II were searched for in both museums and the Danish library catalogue REX, accessing collections of literature from all institutes of the University of Copenhagen and the Danish Royal Library.

Results Several historical changes were identified either increasing or reducing chemical exposures in Danish firefighting. New sources of chemical exposures included more toxic smoke combustion from plastic materials introduced in the 1950s, exhaust from new diesel engines introduced in the 1960s and new assignments relating to chemical cleanups in the 1970s and traffic accidents in the 1990s. Nevertheless, several improvements in the profession's work environment may have reduced chemical exposures, for example, mandatory use of more effective respiratory protection equipment in the 1970s, incorporation of mechanical exhaust systems in the 2000s, and filters and selective catalytic reduction (SCR) for diesel engines in the 2010s.

Conclusion The data showed that the work environment in Danish firefighting has undergone several improvements during the last decades. At the same time, however, several new chemical hazards have also been introduced. Consequently, no strong conclusions as to whether Danish firefighting overall has become a less hazardous profession can be made.
\end{abstract}

Key terms Denmark; exposure assessment; exposure assessment methodology; extreme environment; fireman; history science method; smoke exhaust; truck exhaust.

Firefighters are exposed to several chemical hazards (ie, fire smoke and exhaust from fire trucks) in combination with extreme high temperatures, night work, and high levels of physical and psychological stress, which are more uncommon in the contemporary general work force (1). Chemical exposures encountered by firefighters depend on several factors, including the combustion products from different types of fires, use of effective protection equipment, cumulative number of extinguisher runs, the use of mechanical exhaust systems at fire stations and additionally held assignments besides firefighting $(2,3)$.

Historical changes in important factors may, moreover, have modified exposures in firefighting at different points in time. Previous studies, primarily from the USA and Australia, have suggested that increases in the use of synthetic plastics in furnishing and building materials during the 1950s have generated more toxic combustion products and that modern fires display a totally different and unpredictable burning behavior (ie, by burning quicker) (2). Important improvements in the fire service initiated in the 1960s, nevertheless, resulted in a more regular use of developed effective protection gear (4), and in the 1980s exposures from fire truck exhaust were further reduced with the introduction of mechanical exhaust systems for garages (5). Due to a more efficient fire service and fire safety standards, modern firefighters also only spend $0.75-2.7 \%$ of their time at fires per year (6) and today provide a range of other services to their community (3).

1 The Danish Cancer Society Research Centre, Copenhagen, Denmark.

Correspondence to: Julie Elbæk Pedersen, The Danish Cancer Society Research Center, Strandboulevarden 49, 2100 Copenhagen $\emptyset$, Denmark. [E-mail: juliep@cancer.dk] 
Where adequate information on potential changes in acknowledged exposure factors is not available in existing scientific literature, researchers might consider alternative strategies in addition to traditional epidemiological explorations. Studies in occupational areas other than firefighting have shown the possibilities of retrieving historical information from national historical archives when assessing country specific changes in work-related exposure patterns, eg, styrene exposure, dry cleaning, and nickel (7-9). In occupational epidemiology, searching for historical literature to complement common exposure assessment methods [eg, self-reported exposures, job-exposure matrices (JEM), measurements, and expert assessment] is, nevertheless, not a strategy that is often used. As a result, only few studies on firefighting have accounted for country-specific historical changes in important exposure factors $(5,10,11)$ and consequently, interpretations of international comparisons of results from especially historical cohort studies on firefighters with long follow-up time are challenging.

Using historical methods, this paper constitutes the first step in describing and evaluating overall historical changes in Danish firefighting possible modifying exposures and exploring whether these changes are comparable to those pointed out in international literature.

\section{Methods}

The historical analysis we engaged in was mainly focused on describing changes in protection equipment, the use of mechanical exhaust systems, and factors associated with the time firefighters would spend extinguishing fires. Previous international evaluations on firefighting have highlighted all these elements as important exposure factors $(2,3)$. In our study, both primary and secondary material were included and searches for these historical sources were undertaken in different ways complementing each other. Primary sources were gained from museums, which included a unique set of original reports from the former Smoke Diver Laboratory in Copenhagen. These reports provided data from 1932-1980 with descriptions of protection equipment and measurements of smoke composition from different fires and exhaust from garages.

Furthermore, we conducted electronic searches for secondary material in the Danish library catalogue REX, accessing collections of literature from all institutes of the University of Copenhagen and the Danish Royal Library. A restriction in our first search was the time period of interest, which was constrained to cover firefighting in Denmark after World War II. When further restricting the search to books, which hold more detailed descriptions compared to journals, the first search yielded 269 results. After evaluating the title and abstract, we identified 42 books for further consideration and these were screened again in more detail. This search resulted in an inclusion of a total of six books, most of which were anniversary books published by fire departments located in different parts of Denmark and based on the fire departments' own historical records and data retrieved from local historical archives (ie, museums and municipal archives).

One book held statistics on the development in fire incidents in Denmark (12), but since this information was restricted to the time prior to 1995 , we supplemented this finding with recent statistics published by the Danish Emergency Management Agency (13). Lastly, we also included a report on historical changes in Danish firefighting published by the labor union FOA representing professional firefighters, which was identified in a former research project on Danish firefighters (14).

We then reviewed all the gathered material to explore changes in the exposure factors of our main interest and focused on how primary sources from museums, reports and statistics were supplemented by included secondary sources. To compare our findings on historical changes in Danish firefighting with those highlighted in international literature, we reviewed existing epidemiological firefighter studies.

\section{Results}

In Denmark, municipalities usually manage firefighting, but in several areas firefighter assignments have been contracted out to private enterprises that employ full- and part-time firefighters. In other specific areas, volunteer firefighters, who have similar working conditions to their part-time counterparts, have covered firefighting services according to tradition. In addition, a governmental emergency agency with regional departments throughout the country has provided rescue training and assistance.

\section{Career firefighting in Denmark in 1945}

Around the time of WWII, firefighters in Copenhagen were primarily employed full-time, and standard equipment consisted of box calf leather boots, custom-made leather gloves covering the forearms, a stainless-steel helmet with a small cape shielding the neck, and woolen coat and trousers $(15,16)$. The outfit did not serve as efficient protection against chemical exposures, but was mainly functioning as a uniform with a relative high melting point and fire resistance (17).

The fire brigade in Copenhagen also had a specialized trained unit using closed circuit self-contained 
breathing apparatuses (SCBA), which removed exhaled carbon dioxide and simultaneously added new oxygen from a cylinder. When wearing this equipment, the specialized training unit could enter a burning structure to fight a fire. At this point in time, the equipment comprised a relatively good protection from smoke, but - compared to modern equipment - there was a higher risk for leaks resulting in a reduced protection against dangerous contaminants from the ambient environment and an increased risk of acute inhalation injuries from both chemicals and hot air (17). Filter masks were also frequently used as respiratory protection. These masks contained activated charcoal and, when used properly, could absorb significant amounts of soot and especially larger particles. Finer particles and gasses, such as carbon dioxide and carbon monoxide, could pass easily however $(17,18)$.

\section{Measurements of exposures}

In both the pre- and post-war period, the capital fire departments were also privileged by having the Smoke Diver Laboratory exploring toxic smoke components from fires and improving firefighting gear, including respiratory protection equipment (17-19). Examples of critical measurements collected after WWII are shown in table 1 . The most dangerous concentrations detected showed carbon monoxide, carbon dioxide and oxygen to be $24000 \mathrm{ppm}, 89000 \mathrm{ppm}$ and $109000 \mathrm{ppm}$, respectively, which were lethal for firefighters not wearing protection equipment or simply filter masks (table 1) $(18,19)$.

Firefighters' use of respiratory protection in 1945 were based on recommendations issued by the Smoke Diver Laboratory prior to the war, which were founded on measurements of chemical concentrations obtained at different fire scenes (table 2). According to the written guidelines, firefighters participating in controlling and extinguishing the fire (known as the "knockdown phase") were recommended to use SCBA when these were available. The use of filter masks was to be restricted to situations with sufficient air ventilation and where the environment was not as hot or smoky but still contained products of combustion from small fires (the "overhaul phase") $(3,18,19)$.

Around the time of WWII, fire departments were, moreover, equipped with modern fire trucks that aided emergency efforts $(16,20)$. However, measurements collected by the Smoke Diver Laboratory showed that exhaust gases from running truck engines at fire incidences and in fire station garages also exposed firefighters to chemical hazards. Lethal poisoning levels for carbon monoxide were shown after $1 / 2$ hour of exposure, while examinations of smaller closed garages showed lethal levels after just few minutes. Based on these measurements, the Smoke Diver Laboratory recommended the ventilation of garages for health reasons as well (20). Chemical exposures to polycyclic aromatic hydrocarbons and nitrogen oxides from fire trucks were probably increased from 1962, when diesel fire trucks were introduced in Denmark (12), exposing firefighters to new complex mixtures of gases and particulates at the fire station and during fire extinguishing efforts.

\section{Rural fire departments}

After the German forces lost WWII, their abandoned respiratory protection equipment and trucks were collected and redistributed to Danish fire departments improving the rather poor working conditions in many areas (21-23). In these early eras of modern firefighting in Denmark, a significant gap existed between the large urban fire departments and those located in rural areas. Rural fire departments were minor in size and consisted primarily of craftsmen working part time or voluntarily. These firefighters would perform standby or on-call fire service and wear their own civil clothes when participating in firefighting activities. Modern equipment was generally limited and the only respiratory protection available was filter masks. Due to the limited protection equipment, countryside fire departments would generally use a more defensive strategy and fight fires from the outside unless victims had to be saved. Rural firefighters were, consequently, less effective due to the restricted time they could spend extinguishing fires without risking acute health effects in close proximity to fires (12).

Table 1. The five most critical concentrations of carbon monoxide, carbon dioxide and oxygen measured at fire incidents in 1945-1951. Adapted from Danielsen (17).

\begin{tabular}{cccc}
\hline Year & $\begin{array}{c}\text { Carbon monoxide }(\mathrm{CO}) \\
\text { ppm }\end{array}$ & $\begin{array}{c}\text { Carbon dioxide }\left(\mathrm{CO}_{2}\right) \\
\text { ppm }\end{array}$ & $\begin{array}{c}\text { Oxygen }\left(\mathrm{O}_{2}\right) \\
\text { ppm }\end{array}$ \\
\hline 1945 & 37000 & 74000 & 129000 \\
1947 & 24000 & 89000 & 109000 \\
1947 & 10000 & 31000 & 161000 \\
1948 & 10000 & 81000 & 108000 \\
1951 & 11000 & 33000 & 165000 \\
\hline
\end{tabular}

Table 2. Recommendations for firefighter respiratory protection while working at a fire scene based on quantities of smoke and air indicating critical concentrations of oxygen and carbon monoxide. Adapted from Danielsen (17).

\begin{tabular}{llrrl}
\hline $\begin{array}{l}\text { Quantities } \\
\text { Smoke + Air }\end{array}$ & $\begin{array}{r}\text { Oxygen } \\
\left(\mathrm{O}_{2}\right) \mathrm{ppm}\end{array}$ & $\begin{array}{c}\text { Carbon monox- } \\
\text { ide }(\mathrm{CO}) \mathrm{ppm}\end{array}$ & Necessary pulmonary protection \\
\hline 1 & 0 & 95000 & 13000 & Closed circuit self-contained \\
1 & 1 & 150000 & 6500 & breathing apparatus (SCBA) \\
1 & 2 & 168000 & 4300 & Filter mask containing activated \\
1 & $3-11$ & - & - & charcoal \\
1 & $>12$ & 197000 & 1000 & Simple filter mask \\
\hline
\end{tabular}


Improvements in the work environment

The need for a more efficient fire service in areas outside the capital, but also in Copenhagen with its growing population, emerged after WWII. A commission was therefore established seeking to streamline the equipment, service management and preventive standards regarding fire safety.

In the 1950 s, standardization of effective respiratory protection equipment resulted in the introduction of negative pressure open-circuit SCBA. These new developed respiratory devices were used as gasmasks and would have a circuit breathing set linked to the air inlet. Air was delivered when the firefighter was breathing in, which would reduce the pressure in the mask compared to the outside pressure. Leaks in this type of equipment would therefore cause inhalation of contaminated air and thereby reduce the protection offered when extinguishing fires (12).

These open-circuit SCBA were easier to use and maintain compared to closed-circuit SCBA but were not used regularly for many years by firefighters and often only during the knockdown phase. It was not until the 1970s that use of SCBA by all Danish firefighters participating in both the knockdown and overhaul phase became mandatory $(12,14)$. Over the years this respiratory protection equipment was also improved. In the beginning of the 1980 s, positive pressure SCBA were introduced, whereby inward leaking would under most circumstances be prevented due to the constant stream of uncontaminated air out of the device. Today, municipal firefighters use positive pressure-demand open-circuit SCBA (14), and improved positive pressure-demand closed-circuit SCBA are normally only used when entering a burning building structure to save victims or when engaging in long lasting operations/specific purposes (ie, fires in tunnels) (12).

In 1987, glass reinforced plastic helmets and fire resistant synthetic black suits, improving dermal protection, also became mandatory to wear (15). The suit was replaced during the years with better-quality models and today firefighters wear a water- and fire-resistant four layered fire suit. The current model is, moreover, beige so contamination can be detected (16) and hygienic standards regarding cleaning of suits and gear, including washing of firehoses, have also been enhanced (14).

For a further reduction of dangerous chemicals in modern firefighting, exhaust devices to reduce diesel exhaust in garages became available at fire stations in the early 1990s, but were not fully implemented in Denmark until the early 2000s. In the 2010s, exposure to diesel exhaust was further reduced by the implementation of filters and selective catalytic reduction (SCR) for diesel engines (14).
Structural differences between rural and urban firefighters

Despite improvements in firefighting respiratory protection equipment with negative pressure SCBA introduced in the 1950s, filter masks were, nevertheless, still the most frequently available respiratory protection for several rural fire departments until the late 1960s (12).

Standardization of educational matters, including instructions in the accurate use and maintenance of respiratory protection equipment, had resulted in the establishment of a firefighter school in the 1960s. The school was, however, only mandatory for full-time firefighters and was located in Copenhagen, which resulted in part time/volunteer firefighters operating in rural areas having to still train at local fire departments $(12,15,19)$. It was not until the late 1980 s that part time/volunteer firefighters were required to complete the same advanced education program as full-time firefighters (12).

\section{Fire statistics and new assignments}

In the 1970s, standardization efforts in reporting systems also emerged and were used to measure national improvements in the fire service and fire safety standards throughout the years. Danish statistics show that the percentage of large fires declined from 7\% in 1970 to $4.5 \%$ in 1990 and apart from the 1970s, where the oil crisis resulted in an increase in chimney fire incidents, the average number of fire incidents per 1000 residents per year in the whole country were shown to be relatively stable from 1970 to 2015 , with 2.8 and 2.3 fires, respectively (figure 1) $(12,13)$.

Documented improvements of the fire service may have led to further rationalization efforts, which included new assignments. In the beginning of the 1970s, firefighters became responsible for cleanups after chemical spills and accidents, which increased over time from 1460 registrations in 1977 to 3023 in 1990 (12). In 1992, firefighters also became formally responsible for participating in other emergencies, including traffic accidents and natural disasters (12).

\section{Discussion}

To assign proxies of exposure to different groups of workers in historical cohort studies, an evaluation of the potential influence of historical changes on exposure factors needs to be incorporated. Nevertheless, this has been limited in most previous studies focusing on firefighting. In this paper, we have demonstrated the possibilities of using historical methods to collect valuable information on developments in Danish firefighting, which indicate 


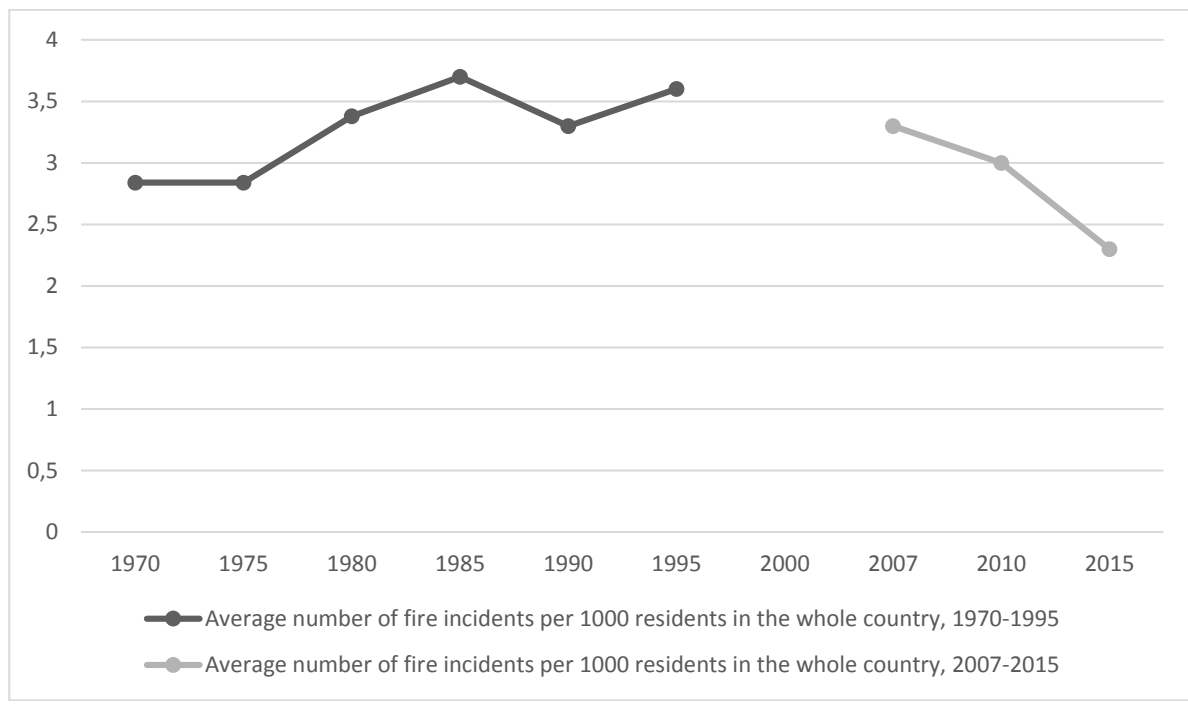

Figure 1. Danish fire statistics covering the periods 1970-1995 and 2007-2015. NOTE: Danish firestatisticscovering the period 1970-1995 and 2007-2015 were adapted from Haurum (12) and Beredskabsstyrelsen (13), respectively.

important changes in exposure to combustion products from fires and exhaust from firefighter vehicles over time for different types of firefighters working in the same era and, moreover, for firefighters working several years in the profession. Consequently, this present evaluation of historical changes in the firefighting profession indicates that assigning proxies of exposure to different groups of firefighters over time is a complex issue.

\section{Historical changes in Danish firefighting}

Firefighters have always been exposed to serious chemical hazards relating to toxic constituents of smoke. Nevertheless, the smoke became more toxic in the 1950s due to the introduction of plastic materials in furnishing and building materials, thus exposing firefighters to additional health risks. The widespread use of fire trucks with diesel engines in the 1960s also formed an additional source of exposure together with new assignments in the 1970s and 1990s relating to cleanups after chemical spills and assistance at traffic accidents, respectively.

On the other hand, our study also shows that historical changes in important factors may have reduced Danish firefighters' exposure to this more toxic smoke combustion and diesel exhaust in recent decades. These changes include the mandatory use of more effective respiratory protection equipment in the 1970 s, a reduction of large fires throughout the years, improved hygienic standards regarding firefighter gear, full incorporation of mechanical exhaust systems in the beginning of the 2000s, and implementation of filters and SCR for diesel engines in the 2010s.

In the first decades following WWII, we further discovered significant structural differences in the work environment between full- and part time/volunteer firefighters, normally employed in different parts of the country. For example, effective protection gear and educational matters, which included standardized training in the use of this gear, were in general not available for firefighters operating outside the capital area. Differences in the work environment, nevertheless, slowly diminished with effectuated nationwide standardization initiatives from the 1970s. Figure 2 gives an overview of historical changes relating to reductions and introductions of chemical exposures in Danish firefighting.

\section{Use of protection equipment}

Despite the introduction of effective respiratory devices and their mandatory use in the 1970s, Danish firefighters did not use the devices regularly during all phases of firefighting for many decades to come due to a workplace culture in the profession, which included getting dirty from smoke and soot during firefighting efforts, and an underestimation of exposure levels and chemical hazards. The heavy weight of the devices and difficulties communicating while wearing them also contributed to the insufficient use (14).

International studies have especially focused on firefighters' use of respiratory protection equipment when evaluating their exposure to smoke. The implementation of mandatory use of respiratory equipment in the US were shown to reduce the number of smoke inhalation injuries in subsequent years by as much as $80 \%$ (4). However, recent international studies show that modern firefighters still do not use respiratory protection equipment when necessary, which especially concern the overhaul phase of firefighting (24). A recent Danish study on young conscripts training to become firefighters showed that during firefighting activities there was little 

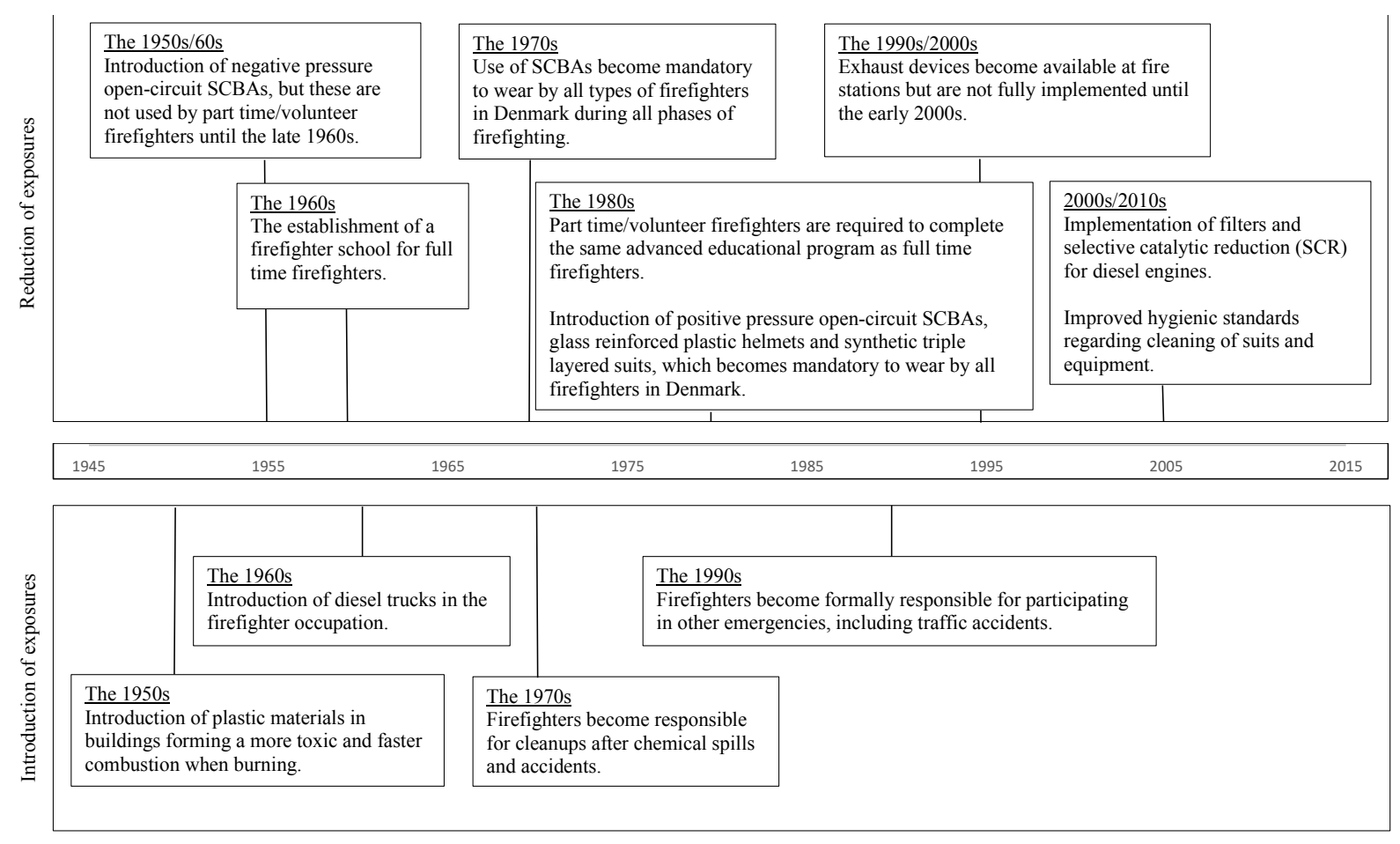

Figure 2. Overview of historical changes of both reductions and introductions of chemical exposures in Danish firefighting.

inhalable particulate matter exposure indicating that the self-contained breathing apparatus was a highly efficient barrier toward particles. Chemical exposure was, nevertheless, observed when the protection equipment was not worn during instructions at locations considered as safe zones. Moreover, the study showed that skin exposure to soot occurred by handling contaminated equipment (25). After the use of respiratory protection equipment became mandatory in Denmark, Danish firefighters may have had a reduced risk of experiencing acute inhalation injuries during especially the first phases of firefighting, but have still been at risk of exposure to more toxic components from smoke if protection equipment has not been worn at all times during firefighting activities. More effective suits also provide an improved dermal protection but firefighters who are able to work in more challenging conditions than before due to improvements in protection equipment might risk more contaminated gear exposing them dermally to chemicals if they do not adhere to improved standards of hygiene (ie, effective and regular cleaning of gear).

\section{International historical changes}

When comparing our findings with those described in international literature, the more widespread use of modern SCBA also took place during the 1960 s and 1970s in the different US states (26), and mandatory use of respiratory equipment was implemented in 1977 (27). Mechanical exhaust systems were introduced more recently in Denmark (14) compared to Australia and the US, which introduced these systems in 1985 and the early 1990s, respectively $(5,28)$. This difference implies that Danish firefighters working in more recent eras may have experienced higher cumulative exposures to diesel exhaust from fire trucks compared to firefighters operating in Australia and the US.

\section{Weaknesses and strengths}

The present paper has focused on describing historical changes in exposure to fire smoke and exhaust from fire trucks in Danish firefighting and, therefore, do not cover descriptions of how historical changes might have modified additional hazards (ie, thermal, physical, psychological exposures). Our comparisons between historical changes in important selected exposure factors in Danish firefighting and changes in similar factors described in international literature may in addition be challenged by national differences, ie, geographical differences influencing the frequency of wildland versus urban fires, the organization of fire departments and fire- 
fighter tactics. Even firefighting within the same national context may, moreover, differ due to wide variation in several aspects (ie, type of firefighter employment and firefighting fought in rural, urban and industrial areas), even in a small country like Denmark. Future aspects such as climate changes, hazards of new techniques such as electric and hydrogen cars and burning of new nanomaterials may additionally form new challenges in firefighting and contribute to differences in exposures both within and between countries.

Moreover, firefighters often hold a second job and may have had substantial occupational histories other than as firefighters potentially forming additional hazards interacting with those in firefighting. Studies of firefighters' occupational history patterns besides firefighting are therefore warranted and ongoing in Denmark.

In occupational epidemiology, it is not common to search for historical literature. Using this strategy, we identified nuanced historical information, which have not been evaluated in most international literature on chemical exposures in firefighting before, ie, differences in exposure factors by type of firefighter employment, educational matters and additional assignments held by firefighters. Moreover, exposures are often assumed to vary between different types of firefighters (full- versus part-time/volunteer) due to differences in the accumulated number of fire runs. Yet, our findings reflect a more complex picture of differences in exposures encountered by different types of firefighters especially in earlier eras. We were furthermore able to compare several historical changes in Danish firefighting with those identified in international literature.

Due to the complexity in exposures in firefighting over time for different groups of firefighters, it would be a challenge to integrate this new information into a JEM. However, we believe that our findings still provide a valuable resource by demonstrating that alternative strategies are useful in uncovering historical modifications in exposures in specific occupations. This historical strategy may be adapted by other epidemiological studies to complement common exposure assessment methods and justify the analyses being conducted. Future studies evaluating historical changes in occupations with less complex exposures may succeed in providing information that can be integrated into a JEM thereby improving international comparisons of results when exploring associated health effects.

\section{Concluding remarks}

Historical changes in Danish firefighting have resulted in various modifications in chemical exposures (ie, smoke and exhaust from fire trucks) taking different directions. Mandatory use of more effective respiratory protection equipment, a reduction in the number of large fires, incorporation of mechanical exhaust systems and filters for diesel engines have probably reduced Danish firefighters' exposure to smoke and diesel exhaust, while more toxic combustion from plastic materials, diesel engines and new assignment relating to chemical cleanups have levied new sources of chemical exposures. Therefore, no firm conclusions as to whether Danish firefighting overall has become a less hazardous occupation can be made. Epidemiological studies that include information on occupational historical changes in the exposure assessment when exploring associated negative health effects are warranted.

\section{Acknowledgements}

The authors would like to thank participating firefighter museums for providing important historical information on Danish firefighting.

\section{Funding}

Funding was partly provided by the Danish Working Environment Research Fund. The funders had no role in the study design, data collection and analysis, decision to publish, or preparation of the manuscript.

\section{Ethics}

The authors declare no conflicts of interest.

\section{References}

1. Soteriades ES, Smith DL, Tsismenakis AJ, Baur DM, Kales SN. Cardiovascular disease in US firefighters: a systematic review. Cardiol Rev. 2011;19(4):202-15.

2. Guidotti TL, Clough VM. Occupational health concerns of firefighting. Annu Rev Public Health. 1992;13:151-71. https://doi.org/10.1146/annurev.pu.13.050192.001055.

3. IARC. Painting, firefighting, and shiftwork. IARC Monogr Eval Carcinog Risks Hum. 2010;98:9-764.

4. Treitman RD, Burgess WA, Gold A. Air contaminants encountered by firefighters. Am Ind Hyg Assoc J. 1980;41(11):796-802. https://doi. org/10.1080/15298668091425662

5. Glass DC, Pircher S, Del Monaco A, Hoorn SV, Sim MR. Mortality and cancer incidence in a cohort of male paid Australian firefighters. Occup Environ Med. 2016;73(11):761-71.

6. Austin CC, Dussault G, Ecobichon DJ. Municipal firefighter exposure groups, time spent at fires and use of self-contained-breathing-apparatus. Am J Ind Med. 2001;40(6):683-92. https://doi.org/10.1002/ajim.10023. 
7. Kolstad HA, Sonderskov J, Burstyn I. Company-level, semiquantitative assessment of occupational styrene exposure when individual data are not available. Ann Occup Hyg. 2005;49(2):155-65.

8. Johansen K, Tinnerberg H, Lynge E. Use of history science methods in exposure assessment for occupational health studies. Occup Environ Med. 2005;62(7):434-41. https:// doi.org/10.1136/oem.2004.016493.

9. Sivulka DJ, Seilkop SK, Lascelles K, Conard BR, Jones SF, Collinson EC. Reconstruction of historical exposures at a Welsh nickel refinery (1953-2000). Ann Occup Hyg. 2014;58(6):739-60.

10. Baris D, Garrity TJ, Telles JL, Heineman EF, Olshan A, Zahm SH. Cohort mortality study of Philadelphia firefighters. Am J Ind Med. 2001;39(5):463-76. https://doi. org/10.1002/ajim.1040.

11. Daniels RD, Bertke S, Dahm MM, Yiin JH, Kubale TL, Hales TR, et al. Exposure-response relationships for select cancer and non-cancer health outcomes in a cohort of U.S. firefighters from San Francisco, Chicago and Philadelphia (1950-2009). Occup Environ Med. 2015;72(10):699-706. https://doi.org/10.1136/oemed-2014-102671.

12. Haurum G. Dansk Brandvæsen, 1945-1995. [Danish Firefighting, 1945-199]. ]. Hvidovre: Dansk Brandteknisk Institut 2000.

13. Beredskabsstyrelsen. Redningsberedskabets statistik 2016. [The Emergency Management Agency's statistics 2016]. Birkerød: Beredskabsstyrelsen; 2016.

14. FOA. Sådan slukkede vi brande før i tiden - Rapport om brandfolk og kræft. [This was how we extinguished fires in the past - firefighters and cancer report]. København: FOA; 2015.

15. Villadsen KS. Gentofte Brandvæsen 1902-2002, 100 år i ilden. [Gentofte Fire Department 1902-2002, 100 years in the fire]. Villadsen KSK, Niels; Gentofte Brandvæsens Museumsforening; Lokalhistorisk Forening for Gentofte Kommune, editor. Charlottenlund: Gentofte Brandvæsens Museumsforening, Lokalhistorisk Forening for Gentofte Kommune; 2002.

16. Brandvæsen K. Livet er så kort og man er så længe død, røgdykkertjenesten i Københavns Brandvæsen. [Life is so short and you are dead so long, Copenhagen Fire Department's smoke diver unit]. Kbh.: Københavns Brandvæsen; 2013.

17. Danielsen G. Laboratoriets arbejdsopgaver, 1932-1980. Uddrag af arkivet, 5B. [The laboratory's work assignments, 1932-1980. Exstract from the archive, 5B]. København: Københavns Brandvæsen; 1980.
18. Danielsen G. Laboratoriets arbejdsopaver, 1932-1980. Uddrag af arkivet - 6A. [The laboratory's work assignments, 19321980. Exstract from the archive, 6A]. København: Københavns Brandvæsen; 1980.

19. Danielsen G. Laboratoriets arbejdsopgaver, 1932-1980. Uddrag af arkivet - 5A. [The laboratory's work assignments, 1932-1980. Exstract from the archive, 5A]. København: Københavns Brandvæsen; 1980.

20. Danielsen G. Laboratoriets abejdsopgaver, 1932-1980. Uddrag af arkivet - 6B. [The laboratory's work assignments, 1932-1980. Exstract from the archive, 6B]. København: Københavns Brandvæsen; 1980.

21. Brodersen SE. På strejftog i et brandgodt kapitel, Vamdrup Brandvæsen 1948-1988. [On a trip in a burning hot chapter, Vandrup Fire Department 1948-1988]. Brodersen SEVB, editor. Vamdrup: Vamdrup Brandvæsen; 1988.

22. Jensen S. Tårnby brandvæsen, brandvæsnets 75 års jubilæum. Tårnby Fire Department, the fire department's 75 year anniversary]. Jensen S, editor. Kastrup: Tårnby brandvæsen; 2001.

23. Pedersen WS. Gennem ild og vand, Silkeborg Brandvæsen 1854-2004. [Through fire and water, Silkeborg Fire Department 1854-2004]. 1st. ed. Det Fælleskommunale Beredskab G, Silkeborg og Them; Brand og Redning Silkeborg, editor. Silkeborg: Det Fælleskommunale Beredskab, Gjern, Silkeborg og Them; 2004.

24. Baxter CS, Ross CS, Fabian T, Borgerson JL, Shawon J, Gandhi PD, et al. Ultrafine particle exposure during fire suppression--is it an important contributory factor for coronary heart disease in firefighters? J Occup Environ Med. 2010;52(8):791-6. https://doi.org/10.1097/ JOM.0b013e3181ed2c6e.

25. Andersen MHG, Saber AT, Pedersen PB, Loft S, Hansen AM, Koponen IK, et al. Cardiovascular health effects following exposure of human volunteers during fire extinction exercises. Environ Health.. 2017;16(1):96.

26. E.C. H. Respirator protection factors. Informal Report No. LA-6084-MS. La Alamos: Los Alamos Scientific Laboratory at the University of California.; 1976.

27. G.H. P. Standing Order 69 - Mandatory mask rule. Bosten MA: Boston Fire Department; 1977.

28. Peters WC. Diesel Soot: An exhausting problem. Firefighter Engineer. 1992;47-51.

Received for publication: 16 September 2018 